\title{
Comunicação
}

[Communication $]$

\section{Ocorrência de infecção por parvovírus suíno e gastrenterite transmissível em suínos, criados de forma extensiva, em Goiás}

\author{
[Occurrence of porcine parvoviral infection and transmissible gastroenteritis virus infection in swine from \\ extensive raising systems in the state of Goiás, Brazil] \\ D.L. Barthasson ${ }^{1}$, W.M.E.D. Brito ${ }^{2 *}$, J. Sobestiansky ${ }^{3}$, S.P.M.B. Caixeta ${ }^{4}$, \\ T.M.T. Miranda ${ }^{5}$, L.A. Silva \\ ${ }^{1}$ Aluna de pós-graduação - EV-UFG - Goiânia, GO \\ ${ }^{2}$ Instituto de Patologia Tropical e Saúde Pública - UFG - Goiânia, GO \\ Rua $235 \mathrm{~s} / \mathrm{n}$ - Setor Universitário \\ 74605-050 - Goiânia, GO \\ ${ }^{3}$ Escola de Veterinária - UFG - Goiânia, GO \\ ${ }^{4}$ Bolsista de iniciação científica $-\mathrm{CNPq}$ \\ ${ }^{5}$ Aluna de pós-graduação - IPTSP-UFG - Goiânia, GO
}

\begin{abstract}
A parvovirose (PV) e a gastrenterite transmissível (TGE) estão entre as enfermidades virais que podem causar grandes perdas econômicas na suinocultura. A parvovirose suína manifesta-se clinicamente com problemas reprodutivos, caracterizados por elevados índices de morte embrionária e/ou fetal além de grande número de fetos mumificados e natimortos (Borges et al., 2003). É considerada como a principal causa de morte embrionária e fetal em rebanhos suínos do mundo (Mengeling, 1999). A TGE acomete suínos de todas as faixas etárias e em leitões lactentes pode ocorrer elevada letalidade (Sobestiansky et al., 1999a). A infecção ocorre em várias partes do mundo e, apesar de a infecção ter sido registrada no Brasil, não houve disseminação para animais em outros rebanhos (Sobestiansky et al., 1999a).
\end{abstract}

A criação de suínos de forma extensiva ou de subsistência é frequente em propriedades periurbanas e rurais em todo o Brasil. Devido às precárias condições higiênico-sanitários a que a maioria desses animais está submetida, elas podem ser responsáveis pela disseminação de vários patógenos (Rodriguez et al., 2003). Este trabalho teve por objetivo estudar o status sanitário de suínos criados extensivamente em municípios do estado de Goiás quanto à presença do vírus da PV (PPV) e do vírus da TGE (TGEV).

Foram colhidas 171 amostras de sangue de suínos em seis municípios de Goiás, localizados em um raio de $150 \mathrm{~km}$, tendo como epicentro a cidade de Goiânia. Noventa e sete soros foram coletados de suínos de criações de subsistência em 12 propriedades onde os animais eram criados de forma extensiva ou sob o sistema extensivo de criação de suínos (SECS). Setenta e quatro amostras foram obtidas de animais tipo banha em um frigorífico local, cuja rotina era também o abate de suínos provenientes de SECS.

$\mathrm{O}$ diagnóstico de $\mathrm{PV}$ foi realizado por meio da técnica de inibição da hemaglutinação (JOO et al., 1976), e o da TGE por meio da técnica de soroneutralização, segundo metodologia proposta por Romero et al. (1987).

Os resultados para PPV encontram-se na Tab. 1. Das 171 amostras analisadas, 25 (14,6\%) 
reagiram positivamente ao teste e, destes, 19 $(76,2 \%)$ procediam das criações extensivas e seis $(23,84 \%)$ de animais do frigorífico. Esta frequência pode ser considerada baixa quando comparada à encontrada por Rodrigues et al. (2003). Aguiar et al. (2006) detectaram 7,7\% de positividade. Essas diferenças podem refletir variações no manejo sanitário dos animais amostrados ou na menor circulação do vírus nesse tipo de criação em Goiás. Três $(25,0 \%)$ das 12 propriedades apresentaram, pelo menos, um animal reagente. $\mathrm{O}$ índice de soropositividade entre as propriedades variou de $27,2 \%$ a $73,9 \%$.

Tabela 1. Resultados das análises de amostras de soro de suínos de Goiás criados extensivamente para pesquisa de anticorpos para o parvovírus suíno (PPV)

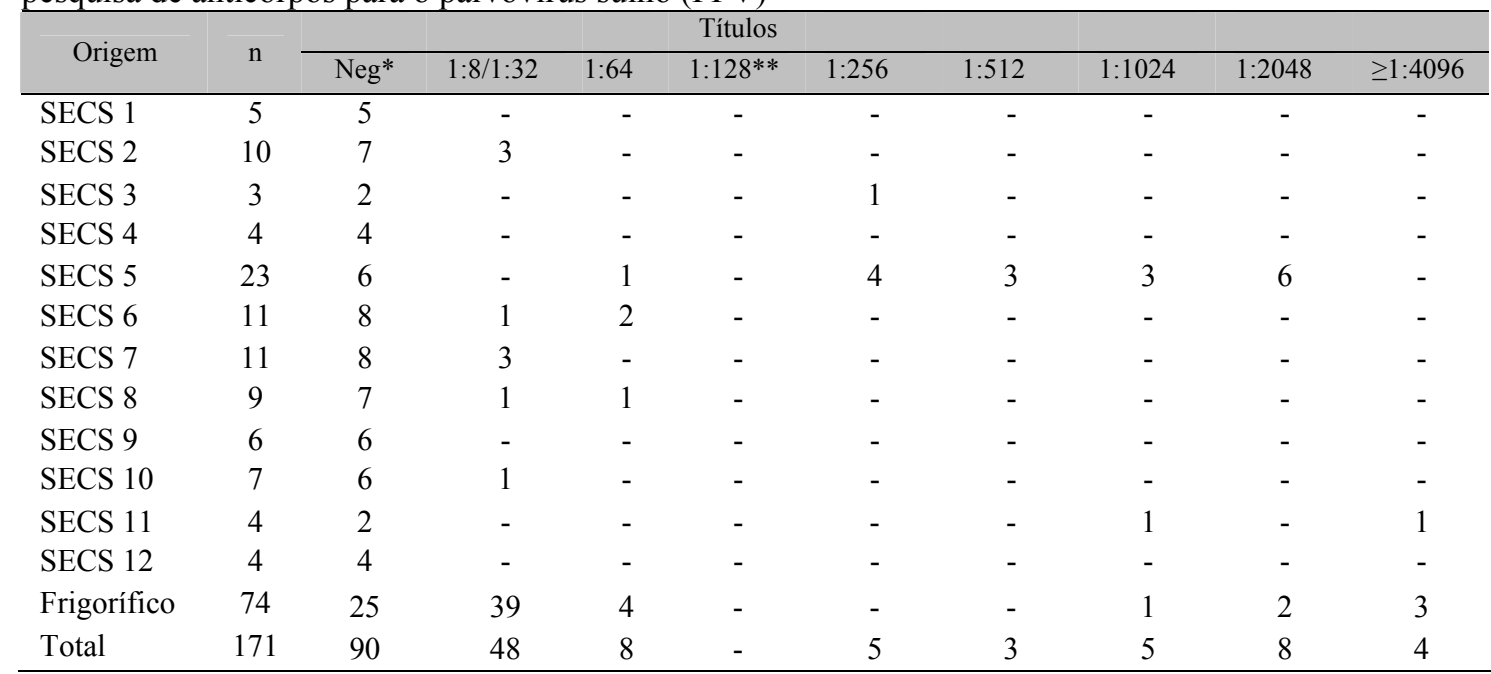

* Negativos.

** Títulos considerados soropositivos de acordo com o CEDISA.

O título de anticorpos para PV nas propriedades variou de $\leq 1: 8$ a 1:4096 e, nas amostras coletadas em frigorífico, de 1:1024 a 1:4096 (Tab. 1). Em uma das propriedades, além de ter sido verificada a maior frequência de soropositividade $(73,9 \%)$, foi também observada maior variação nos títulos de anticorpos (1:256 a 1:2048). Segundo Sobestiansky et al. (1999a), essa situação pode refletir infecção em evolução, sendo esse o perfil sorológico mais frequentemente encontrado em rebanhos suínos no Brasil.

Um fato relevante a ser ponderado é a presença de animais considerados suspeitos nos plantéis. Neste trabalho, oito amostras (4,7\%) apresentaram título de anticorpos de 1:64, sendo quatro nas criações extensivas e quatro no frigorífico. De acordo com a técnica empregada, soros que apresentam esse título são considerados suspeitos da infecção. Sobestiansky et al. (1999b) apontaram que, em criações tecnificadas, títulos baixos de anticorpos contra o PPV, de até 1:64, são indicativos de vacinação.
Como os animais analisados neste estudo não eram vacinados, a presença de anticorpos, mesmo que em baixos títulos, sugere contato prévio com o vírus. Desse modo, o coeficiente de positividade obtido neste trabalho aumentaria para $47,4 \%$, e o número de propriedades infectadas seria de oito $(66,7 \%)$.

Em relação à TGE, apenas 136 amostras foram analisadas. As restantes não puderam ser analisadas devido à citotoxicidade e/ou insuficiência e hemólise da amostra. Nenhum dos soros analisados apresentou anticorpos contra TGE. Este resultado é semelhante ao observado por Brentano et al. (2002) que não identificaram animais reagentes em amostras de soro suínos de SECS, provenientes de vários estados.

Este estudo analisou um tipo particular de população suína, caracterizado por animais criados de forma extensiva e/ou de subsistência, presente não só no Estado de Goiás, mas também em outras regiões no Brasil. As más condições 
higiênico-sanitárias, a não vacinação e o não monitoramento sorológico habitual para as infecções frequentes na população suína são considerados fatores de risco e até facilitadores de infecções, além de provável meio de perpetuação de infecção no plantel (Sobestiansky et al., 1999a; Sobestiansky et al., 2002).

Este foi o primeiro trabalho soroepidemiológico para ambos os vírus realizado nesse tipo de população suína em Goiás. Apesar de não permitir estimativas sobre a prevalência dessas enfermidades nesse segmento da população suína, os resultados permitem concluir que o PPV, mas não o TGEV, está circulando nas criações extensivas de suíno no Estado de Goiás.

Palavras-chave: suíno, criação extensiva, parvovirose

\begin{abstract}
The serological status of porcine parvovirus (PPV) infection and transmissible gastroenteritis virus (TGEV) infection were determined in swine from extensive raising systems in the state of Goiás, Brazil. Ninety-seven serum samples were collected from animals in 12 extensive farms distributed in six cities located nearby Goiânia, GO, and 74 samples were collected from animals in a slaughterhouse in Goiania, GO. For the PPV-specific antibody detection, the hemaglutination inhibition test (HI) was used; and for TGE antibody detection, the serum neutralization test was performed. Results showed that 25 out of the total 171 (14.4\%) analyzed sera were positive for PPV antibodies, and the HI titers varied between 256 to 4,096. None of the 136 serum samples analyzed for TGEV was positive. This is probably the first study that detected PPV and TGEV-specific antibodies in swine herd in the state of Goiás. Data suggest that PPV but not TGEV circulated between and among this population of swine in that state.
\end{abstract}

Keywords: swine, extensive raising, parvovirosis

\section{AGRADECIMENTOS}

À Pfizer Saúde Animal, à Fundação de Apoio a Pesquisa da UFG e CNPSA-EMBRAPA, pelo apoio financeiro e auxílio na análise das amostras. Aos colegas Fabiano Meyer e Marcos Souza e aos acadêmicos do curso de Medicina Veterinária da UFG, Antonio dos Santos Neto e Gustavo Climber, pelo auxílio na coleta das amostras.

\section{REFERÊNCIAS BIBLIOGRÁFICAS}

AGUIAR, D.M.; CAVALCANTE, G.T.; DIB, C.C. et al. Anticorpos contra agentes bacterianos e virais em suínos de agricultura familiar do município de Monte Negro, RO. Arq. Inst. Biol. São Paulo, v.73, p.415419, 2006.

BORGES, V.F.; BARCELOS, D.E.; WENTZ, I. et al. Parvovirose suína: aspectos do diagnóstico. Suinocult Foco, v.9, p.6-7, 2003.

BRENTANO, L.; CIACCI-ZANELLA, J.R.; MORES, $\mathrm{N}$. et al. Levantamento soroepidemiológico para coronavirus respiratório e da gastroenterite transmissível e dos vírus de influenza H3N2 E H1N1 em rebanhos suínos no Brasil. Concórdia: EMBRAPA/CNPSA, 2002. 6p. (EMBRAPA/CNPSA. Comunicado Técnico, 306)
JOO, H.S.; DONALDSON-WOOD, C.O.R.; JOHNSON R.H. Observations on the pathogenesis of porcine parvovirus infection. Arch. Virol., v.51, p.123129, 1976.

MENGELING, W.L. Porcine parvovirus. In: STRAW, B.E.; D'ALLAIRE, S.; MENGELING, W.L. et al. (Ed.). Disease of swine. 8.ed. Ames: Iowa State University Press, 1999. p.187-200.

RODRIGUEZ, C.A.R.; HOMEM, V.S.F.; HEINEMANN, M.B. et al. Soroprevalência de anticorpos anti-parvovírus suíno em suínos do município de Uruara, Estado do Pará. Arq. Inst. Biol. São Paulo, v.70, p.501-503, 2003.

ROMERO, C.H.; ROWE, C.A.; FLORES, R.S. et al. Comparação entre os testes de soroneutralização e imunodifusão na detecção de anticorpos para o vírus da Doença de Aujeszky em suínos. Pesq. Vet. Bras., v.6, p.39-44, 1987.

SOBESTIANSKY, J. Transmissão de doenças. In: SOBESTIANSKY, J. Sistema intensivo de criação de suínos: programa de biossegurança. Goiânia: Art 3 Impressos Especiais, 2002. p.36-40.

SOBESTIANSKY, J.; BARCELLOS, D.E.S.N.; MORÉS, N. et al. Clínica e patologia suína. Goiânia: Art 3 Impressos Especiais, 1999a. 402p.

SOBESTIANSKY, J.; MORÉS, N.; ROEHE, P.M. Parvovirose suína. Suin. Dinâmica, v.7, p.1-5, 1999b. 